\title{
Conference report: on the international interdisciplinary conference: global African indigenous and derived religions
}

\section{Opinion}

This conference on African Indigenous and Derived Religions (AIR) has scholarly and political aspects. It reflects and awareness of scholars as actors in the field of cultural politics. It is part of a dedicated effort to achieve a new appreciation of African Indigenous Religions and its offshoots in the diaspora. This may look like a rather marginal field, in view of the figures that about $7 \%$ of sub-Saharan Africans and about $2-3 \%$ of Latin Americans adhere to African Indigenous and Derived Religions. ${ }^{1}$ However there is widespread awareness of scholars in the field that AIR's have a pervasive influence on Christianity, especially on the dominant Pentecostal and African Instituted Churches, who make up about a quarter of global Christianity, tendency rising, ${ }^{2}$ and also on sub-Saharan Islam. Likewise the influence of AIR on Roman Catholicism in Latin America is acknowledged. The intrinsic influence of AIR on cosmology and anthropology here has been recognized. ${ }^{3}$ In recent years the spiritual world view and practices of AIR have begun to find interest and resonance in the field of Esotericism and wider audiences in Europe and America, ${ }^{4}$ through sympathetic reports in mass media. Spiritual healing practices based in AIR have been widely adopted in Christian contexts of African countries. ${ }^{5}$ They have recently received recognition as indigenous forms of healing by international organizations. Beyond these interests however the study of AIR is eminently important to the appreciation of African culture, and thus to the identity of Africans and of people of African descent. In a wider view it is thus also essential to the understanding of cultures which have a degree of African influence, most eminently Brazil and the Caribbean, but to varying degrees of most American countries. Regardless of ancestry, these cultures have an essential and formative contribution of African religious concepts to their cultures, often mediated by forms of art.

The primary impulse towards the conference in Juiz de Fora originated at a the first symposium on this theme which was organized by the Pan-African Strategic and Policy Research Group (PANAFSTRAG) $^{6}$ in collaboration with the Obafemi Awolowo University in Il-Ife, State of Oshun, in Nigeria. The PANAFSTRAG is a civil organization with a global network, based in Lagos, Nigeria, engaged in the renewal of African culture. Its chairman, Gen. Ishola Williams, has a background of engagement in UNESCO missions, in government and public affairs. Through his efforts, in collaboration with Prof. David Ogungbile, head of Dept. of Religious Studies at Obafemi Awolowo University, Ile-Ife, and West African representative of the African Association for the Study of Religions (AASR) and the support of scholars worldwide, among them Prof. Afeoseme Adogame (Princeton), secretary general of the International Association for the History of Religions (IAHR) at the time, this symposium came to be organized. The venue was well chosen, both for its academic qualities as for its symbolism: in Yoruba cosmology Ile-Ife is situated at the mythical centre of creation. ${ }^{7}$

Posited at the interface of academia and wider culture, the
Volume 3 Issue 4 - 2019

\author{
Ullrich Kleinhempel \\ Department of Contemporary Spiritual Movements, University \\ of Bavaria, Germany
}

Correspondence: Ullrich Kleinhempel, Department of Contemporary Spiritual Movements, University of Bavaria, Heilstaetten Stzr. 150 90768, Germany, Tel +49-15I-19697960, Email u.kleinhempel@gmail.com

Received: April 23, 2019 | Published: July 15, 2019

conference reached out to practitioners of African Traditional Religions, even though the majority of participants were Christians, Muslims or Esotericists. The conviction was shared, that the study and appreciation of African Traditional Religion is essential for the reaffirmation of African identity in Africa and in the AfroAmerican diaspora as well. Thus the conference announcement stated: "Indigenous African Religions are fundamental to Africans, having a positive cultural identity. Indigenous African Religions collectively face crises of existential proportions, and with the crises arises a fundamental challenge to the humanity of Africans globally. Many aspects of indigenous African religions have become extinct, succumbing to centuries of concerted external and internal pressures to undermine them." " This statement of mission is decidedly dedicated to the "politics of identity". There is consensus that the attainment of a positive self-concept rooted in the appreciation of one's collective cultural identity and heritage is an essential factor towards psychological resilience and well-being. At both conferences strong feelings were repeatedly expressed that the systematic "demigration" of the African heritage has had crippling effects on the self-concept of people of African descent and continues to do so. The disregard for AIR and its concepts-as the religion of people without scripture-which continues well into the presence, and its devaluation as mere "magic" or "superstition" persists and requires attention. A line of scholars, from the 20thcentury onwards, initially mostly Europeans and increasingly African themselves and some from the Americas, have dedicated themselves to correcting these perceptions by researching the complexities and sophistication of philosophy and religious concepts of African Indigenous Religions and world views. A pioneer in this regard has been Placide Tempels FR, ${ }^{9}$ followed by John Mbiti ${ }^{10}$ and others. Increasingly the complex ritual practices of AIR have also come into view. Much work of documentation however needs to be done here. Accordingly to this statement of mission the conferences have reached out to practitioners in the field as well.

The first Global African Indigenous Religions Symposium in IleIfe was attended mostly by scholars from Africa, from the Anglophone and Francophone countries, as well as from North America and Europe. Awareness condensed however that AIR exists since five centuries in the Americas where it has established itself, in somewhat syncretistic 
shapes. The necessity was felt to reach out to the lusophone sphere, in particular to Brazil. The growing literature on Afro-Brazilian religions in Portuguese made it advisable to breach the confines of Anglo mono-lingualism-a limitation perceptible in many publications in the field quoting merely English sources. The need was felt to reach out to establish a transatlantic network. ${ }^{11}$ Success came about when prof. Afeoseme Adogame and prof. Raimundo Barreto of Princeton Theological Seminary presented the project to the Department of Science of Religion at the University of Juiz de Fora, Minas Gerais, and Brazil. Here several excellent studies on Afro-Brazilian religions had been written. Thus prof. Volney J. Berkenbrock had written his dissertation on the religious experience of the Orixas in Candomblé, ${ }^{12}$ The perspective from Brazil as a country of the African diaspora with a living African religious tradition and a self-image of owing essential elements of its national culture to the African heritage proved fruitful. Thus the announcement of the conference in Juiz de Fora declared: "The resilience of indigenous religious traditions in Africa and African-derived religions in the diaspora needs scholarly attention in exploring how and to what extent they are central to everyday lives of Africans and its descendants. Religion is crucial to understanding African peoples as well as their diasporic communities within a global context. Indigenous religions encompass phenomena that are primarily defined in terms of their orality, cosmological and ritual orientation towards specific geo-cultural landscapes. A proper grasp of their complex religious cosmologies, traditions and cultures improves our grasp of African peoples and its descendants in conditions of globality. Religion is a motor for diaspora formation, and for the construction and maintenance of cultural identity and value systems." 13

This text reflects on the function of AIR in preserving the cultura identity of African and their descendants in contexts of domination by others in social, territorial, cultural and religious aspects. It is a function which may be identified in the formation of black churches in the USA too, with their specific forms of hymns, of worship and community building over centuries. The text also reflects a postcolonial "exile" in African societies due to the devaluation of the African heritage by the European and Arab conquerors with their dominant religions. The formation of African Instituted Churches with their inclusion of AIR heritage may be viewed as a dialectic move of cultural reassertion. ${ }^{14}$ Attention has turned however also to the institutions, practices and concepts of AIR's themselves, in monographs or collaborative studies, focussing both on AIR 's in their original context as well as in their migrations into other countries and cultural contexts, ${ }^{15}$ following on pioneering work in the 20th century. ${ }^{15}$ Inevitably in such contexts, painful collective memories of victimization and contempt resurge. Speaking about them has a cathartic function, observable at times in both events. However the thematic introduction to the second conference also recalls the resilience of African cultures, in the face of adversity, and their power to influence and to inspire their environment. Thus the text states: "What makes African religions tick against the backdrop of xenophobia, socioeconomic deprivation in fast secularizing contexts? What explains the resilience of African religious traditions in the face of negative public perception? How and to what extent has African religions and African-derived religions shaped the local contexts, cultures and societies within which they are practiced?" Finally the need to proceed from analyses of the various aspects of AIR, of their cultural and social interrelation with changing and diverse contexts, to syntheses, which could serve as guides to the further development of AIR and as reference texts for those interested in them, is stated as goal: "To what extent do indigenous worldviews and religions remain relevant for both Africans on the continent and their descendants in diaspora especially in a globalizing era? How can we synthesize the belief systems, cosmologies, rituals, practices of indigenous religious traditions into a coherent reference and sacred source book for adherents and non-adherents alike?" Beyond the task of description and documentation of the forms of AIR-threatened with decline or extinction in some areas-the need is also expressed to think from their perspective with regard to challenges of the present, to "respond to global issues of poverty, corruption, conflict, peace, religious freedom and climate change." Some work has been done in this regard. After long adherence to the principles of "arcane discipline" and of oral transmission of knowledge about details of AIR within the bounds of traditional institutions of initiation and contexts of transmissionwhich make the study of AIR frequently extremely arduous - the necessity to proceed to written has been understood in some forms of AIR, especially in the diaspora, as in Umbanda. The publication of such books was perceived by some members as severe breach of rules, as abominable profanation of divine secrets. This critique can clearly be observed, where authors become deliberately opaque, so as not to divulge arcana. Another "defence mechanism" is the assertion that Umbanda can never be codified: "The Umbanda perpetuates the tradition of a not codified form. To keep the methodology alive, it need[s to operate] with the orality for which admittedly the priest is main the responsible, what it implies in a constant dynamism. The Umbandista movement is a unit opened in continuous construction. From the studies of Mircea Eliade, we searched showing as the Sacred itself relates with Umbandista religious space." The idea is of a religion in which ongoing revelations by the spirits preclude any doctrinal systematization. In spite of such pervasive secrecy, which make the idea of textbooks of AIR appear as contradictions in terms, manuals of Umbanda have been published. The broad range of perspectives on this field brought a vast diversity of topics in the presentations of the conference, distributed usually in four parallel sessions, which were well attended. Specialists of different fields participated: from the social sciences, literature, arts, medicine, psychiatry, theology, science of religion, anthropology, history, politics, music, pedagogy, architecture etc. Their special views on issues of AIR complemented each other well and gave rise to spirited debate. With the engagement decidedly on re-appreciation of AIR the participation of Roman Catholic and Protestant theologians as well as of adherents of African Indigenous and Afro-Brazilian religions-like Prof. Ivanir Dos Santos, who is also an ordained priest of Candomblé and Dr. L. R. N. Mlisa, a fully qualified South African Igqirha (sangoma or shaman)-as well as of Umbanda provided for an atmosphere of spiritual exchange, which gave existential depth and personal dimensions to the inspiring intellectual exchanges. Participants engaged in other fields, besides academia, such as in publishing, museums, churches, social work, counselling, medicine civil society politics and arts, added to the professional input and transfer to the conference proceedings. An envisioned visit to an evening ceremony at a house of Umbanda in Juiz de Fora had to be cancelled due to an attack on their temple in which it was vandalized. This served as a reminder that besides the romantic image of Brazil as a tolerant and essentially "syncretistic" country there is also a harsh reality of religious (and cultural) intolerance, which makes life sometimes painfully difficult for adherents of AfroBrazilian religions. Fortunately, prof. Ivanir Dos Santos had arranged a post-conference visit to a noted and splendid temple of Candomblé as part of a post-conference programme in Rio de Janeiro. Besides all the fruitful and inspiring cross-cultural exchanges there were also 
moments of intense emotional sharing, when participants from both sides of the Atlantic discovered similar beliefs, rites and experiences, which could be shared across the language barrier, thanks to the efforts of the engaged interpreters, often faced with intricate specialist vocabulary. The abstracts submitted for this conference have been published in Portuguese and in English - the working languages of the conference - and are available online. ${ }^{15}$

\section{Acknowledgments}

None.

\section{Conflicts of interest}

The author declares that there are no conflicts of interest.

\section{References}

1. Pew-Templeton. Global Religions Future Project. Germany: Folk Religions; 2010.

2. Anderson, Allan. The Globalization of Pentecostalism. Bangor/Wales: Commission Meeting of the Churches Commission and Mission; 2002. $255 \mathrm{p}$.

3. Hollenweger, Walter, Pentecostalism. Origins and Developments Worldwide, Peabody, Mass. Hendrickson Publ. Inc; 1997. p. 25.

4. Kleinhempel, Ullrich Relebogilwe. Covert Syncretism: The Reception of South Africa's Sangoma Practise and Spirituality by "Double Faith" in the Contexts of Christianity and of Esotericism. Open Theology. 2017;3(1):642-661.

5. Oostuizen, Gerhardus C, Stephen D. Edwards, et al. Afro-Christian religion and healing in southern Africa. Lewiston: Edwin Mellen Press [PANAFSTRAG]; 1989. 25 p.
6. Sogoba Mia. Ile-Ife: The Sacred Yoruba City. USA: Cultures of West Africa; 2019.

7. Report of the 1st Global African Indigenous Religions Symposium, Obafemi Awolowo University, Ile-Ife, Osun State, Nigeria. 2016. 6 p.

8. Tempels, Placide, La philosophie bantue. Bantu Philosophy. Paris: Presence Africaine; 1955.

9. Mbiti John S. African Religions and Philosophy. London: Heinemann; 1969. $348 \mathrm{p}$.

10. Berkenbroeck, Volney J. An experiência dos orixás: um estudo sobre a experiência religiosa no candomblé. Petropolis: Editora Vozes; 1995. 289 p.

11. Conferência Internacional e Interdisciplinar: Religiões Africanas e Afrodiaspóricas Globais-Relevância do tema e seus contextos. Brazil: Universidade Federal de Juiz de Fora: 2018.

12. Adogame, Afeoseme. The African Christian Diaspora. London: Bloomsbury Academic Pub; 2013. 208 p.

13. Olupona, Jacob Kehinde, Terry Rey. Òrìșà Devotion as World Religion: The Globalization of Yorùbá Religious Culture. Madison: Univ. of Wisconsin Press; 2008. 592 p.

14. Berglund, Axel Ivar. Zulu Thought-Pattterns and Symbolism. London: C. Hurst \& Co; 1975. 402 p.

15. Lages, Raimundo Barreto, Volney Berkenbrok, et al. Internacional e Interdisciplinar: Religiões Africanas e Afrodiaspóricas GlobaisInternational Interdisciplinary Conference: Global African Indigenous and Derived Religions. Germany: Universidade Federal de Juiz de; 2018. $51 \mathrm{p}$. 